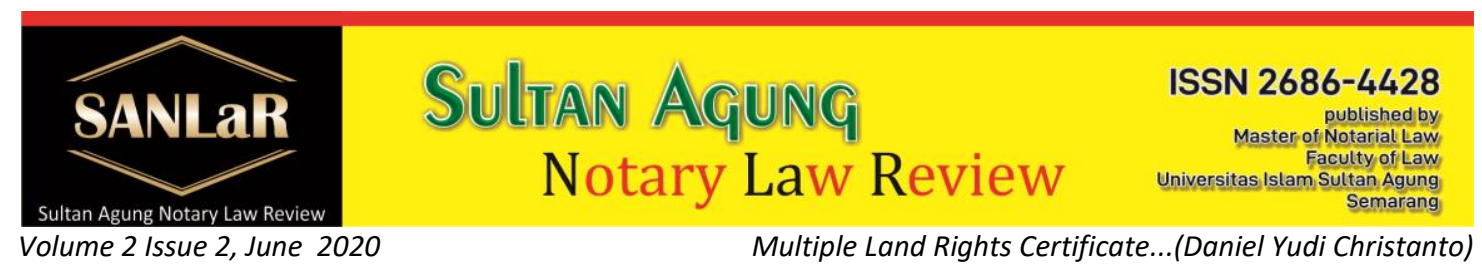

\title{
Multiple Land Rights Certificate Case Settlement Review of Land Registration
}

\author{
Daniel Yudi Christanto*) \\ *) Students of Master of Notary Law, Universitas Islam Sultan Agung (UNISSULA) \\ Semarang, E-Mail: danielyudichristanto@gmail.com
}

\begin{abstract}
The research objective is to know and analyze completion of Multiple Land Rights Certificate in Banyumas Regency. To find out and analyze problems in resolving the case of double certified land rights in Banyumas Regency, and To find out and analyze solution against Settlement of double certified land rights cases in Banyumas Regency. This research is a qualitative research with a normative juridical approach. Based on the results of research and discussion it can be seen that "Double Land Rights Certificate Completion in Banyumas Regency". There are two ways of resolution, namely through the mediation process at the National Land Agency (BPN) to find a solution or win-win solution, but if there is no way out through the mediation process, the settlement is carried out through the litigation process or settlement of cases in court. Constraints in resolving cases of double certified land rights in Banyumas Regency. Due to the change of the Village Head, the new Village Head who does not know that the land already has a certificate will issue a certificate sporadically based on the community's request to issue the land certificate. The problem with the National Land Agency $(B P N)$ is that there are elements who easily issue land certificates due to various factors such as errors in issuing land certificates, both types of certificates of land ownership rights, rights to building and rights to business. Solution against settlement of double certified land rights cases by providing legal protection to the legal owner, such as case No. 26/G/2014/P.TUN.Mks and case Number 30/Pdt.G/2018/PN Pwt, namely that the Plaintiff has received protection in accordance with the applicable law, even though it has to go through a fairly long and timeconsuming judicial process, because the land owner controls the land on the basis of legal and strong rights obtained in good faith, it must be protected by law.
\end{abstract}

Keywords: Multiple; Land; Certificate; Registration.

\section{Introduction}

Land is very closely related to human life. Everyone certainly needs land, not only in their life, humans still need a piece of land to die. The amount of land that can be controlled by humans is very limited, while the number of people who need land is always increasing. In addition to the increasing number of people who need land for shelter, economic, social, cultural and technological progress and development also 
requires the availability of a wider area, such as for plantations, livestock, factories, offices, entertainment venues and roads for means of communication. ${ }^{1}$

In our society, the acquisition of land rights is more often done by transferring land rights, namely through buying and selling. Transfer of rights/transfer of rights over land, is a legal act that aims to transfer rights, including: sale and purchase, grant, exchange, separation and distribution of joint assets and income in companies ${ }^{2}$

Institutional buying and selling of land rights is a legal act of a cash nature, so the sale and purchase of land rights is the most important of the interests of the buyer in relation to the seller. The land rights in question have been transferred to the buyer when the legal action of the sale and purchase is completed before the PPAT. The PPAT deed is proof that the buyer has become the new right holder. The interest of the third party does not always involve the transfer of rights, therefore registration of the transfer of rights only serves to strengthen the position of the buyer in relation to the third party, whose interest may be involved and is not a condition for the transfer of the rights concerned to him. ${ }^{3}$

Transfer is a legal act that is deliberately carried out with the aim of transferring land rights from the transferor to the person receiving the transfer. In Article 20 paragraph (2) UUPA stipulates that property rights can be transferred and transferred. "Switching" means that it happens not because of a legal act (deliberately) but because of a legal event (not intentional), for example being inherited. Meanwhile, "transferred" indicates intentional action so that there is a legal action against the property rights ${ }^{4}$

One of the legal acts of transferring title to land is by buying and selling land. In the current practice of buying and selling land, it is hoped that there will be legal certainty that can guarantee the continuity of these activities through land registration.

The double certificate, namely a plot of land has more than one certificate, ${ }^{5}$ because it brings the result of legal uncertainty for holders of land rights which are highly unexpected in land registration in Indonesia. Multiple certificates often occur in South Sulawesi which results in disputes between certificate holders accusing each other that

\footnotetext{
${ }^{1}$ Saleh, K. Watjik. (1977). Hak Anda Atas Tanah. Jakarta: Ghalia Indonesia. p. 7

2 Salindeho, John. Masalah Tanah Dalam Pembangunan. Jakarta: Sinar Grafika. p. 37

${ }^{3}$ Harsono, Boedi. Hukum Agraria Indonesia, Sejarah Pembentukan Undang-Undang Pokok Agraria Isi dan Pelaksanaannya, Hukum Tanah Nasional Ed. 1. Jakarta: Djembatan. p. 211.

${ }^{4}$ Perangin, Effendi. (1994). Hukum Agraria di Indonesia, Suatu Telaah dari Sudut Pandang Praktisi Hukum. Jakarta: PT. Raja Grafindo Persada. p. 1.

${ }^{5}$ Harsono, Soni. Kegunaan Sertifikat dan Permasalahannya. Yogyakarta: National Seminar on 9 July 1992. p. 6
} 
what they have is true, even though then one of the certificates is a fake where the object listed on the certificate is not the real one, so as to obtain legal certainty regarding land rights certificates. Seeing the reality, the writer tries to find a legal solution to the buying and selling problem uncertified land which so far are still often done by the community. Therefore, the authors feel the need to raise this problem into a study entitled "the settlement by the authorities resolves the double certificate problem"

\section{Research Methods}

The specification used in this research is descriptive research, which is what the respondent states in writing or orally, as well as his real behavior, which is researched and studied as something intact. ${ }^{6}$ The data obtained are then analyzed deductively, this kind of analysis is carried out by thinking through a syllogistic process, with the land law system especially regarding buying and selling as the major premise, while the facts relating to the research material serve as a minor premise. Furthermore, it is connected between the major premise and minor premise and a conclusion is drawn as the research conclusion.

\section{Results and Discussion}

3.1. The settlement of the double land title certificate case is viewed from the purpose of land registration

Based on the results of the author's interview with the National Land Agency (BPN):

"The involvement of the Ministry of Agrarian Affairs and Spatial Planning (ATR)/National Land Agency (BPN) in the settlement of a double certificate case is as a defendant because the Ministry of Agrarian Affairs and Spatial Planning (ATR)/National Land Agency (BPN) is a State Administration Officer (PTUN) who has issued a State Administration Decree, through an Administrative process in the form of the issuance of a Freehold Certificate, if a double certificate case occurs, the settlement can be done in two ways, namely Mediation or the efforts of the Ministry of Agrarian Affairs and Spatial Planning (ATR)/National Land Agency (BPN) by summoning both parties to find a win-win solution. However, if there is no solution, the settlement will be carried out through a court process in which the Ministry of Agrarian Affairs and Spatial Planning (ATR)/National Land Agency (BPN) as the defendant and if one of the certificates has been canceled by the State Administration Officer (PTUN), the Ministry of Agrarian

\footnotetext{
${ }^{6}$ Soekanto, Soerjono. (1982). Kesadaran Hukum dan Kepatuhan Hukum. Jakarta: CV. Rajawali. p. 250
} 
Affairs and Spatial Planning (ATR)/National Land Agency (BPN) is asked to revoke certificates that have been canceled through the trial process".

The mediation process is stated in the Regulation of the Minister of Agrarian and Spatial Planning/Head of the National Land Agency of the Republic of Indonesia Number 11 of 2016 concerning Settlement of Land Cases In Article 12 paragraph 5 that in the case of Disputes or Conflicts not the authority of the Ministry as referred to in paragraph (2), the Ministry can take initiatives to facilitate the resolution of Disputes or Conflicts through Mediation.

If the parties are willing to carry out Mediation, the mediation is carried out based on the principle of deliberation to reach a consensus for the good of all parties.

a. Mediation shall be carried out in no later than 30 (thirty) days.

b. Mediation aims to:

1) ensure transparency and sharpness of analysis;

2) collective and objective decision making;

3) minimize claims for the results of Dispute and Conflict resolution;

4) accommodate information/opinions from all disputing parties, and from other elements that need to be considered; and

5) facilitate the resolution of Disputes and Conflicts through deliberation.

The process of resolving a double certificate case if it cannot be resolved through a mediation process, then the settlement process that is carried out is through the court or called the litigation process. Based on the case example above, the settlement process did not go through a mediation process because one of the plaintiffs' opponents was not present at the trial. According to Andi Maddusila's (plaintiff) statement that:

To minimize land disputes, in this case a double certificate, in this case the role played by BPN as a public servant includes:

a. Reviewing and managing data to resolve cases in the land sector.

b. Collecting lawsuits, preparing response memory materials, preparing appeal memory, cassation memory/counter-memorandum of appeal, memory/counter 
memory review of cases filed in court against individuals and legal entities that harm the state.

c. Collecting data on land problems and disputes.

d. Review and prepare draft decisions regarding land dispute resolution.

e. Reviewing and preparing the concept of decision to cancel land rights with administrative defects and based on the strength of judicial decisions.

f. Documenting.

The National Land Agency (BPN) also has certain mechanisms for handling and settling land cases or disputes, in this case including double certificate disputes, namely:

a. Land disputes are usually recognized by the Ministry of Agrarian Affairs and Spatial Planning (ATR)/National Land Agency (BPN) from complaints.

b. Complaints are followed up by identifying the problem. It is ascertained whether the problem element is the authority of BPN or not.

c. If that is the authority, then the Ministry of Agrarian Affairs and Spatial Planning (ATR)/National Land Agency (BPN) examines the problem to prove the truth of the complaint and determine whether the complaint is reasonable for further processing.

d. If the research results need to be followed up with a physical examination of administrative and juridical data, then the head of the office can take steps in the form of preventing mutations (status quo).

e. If the problem is strategic, it will require the formation of several work units. If it is political, social, and economic, the team will involve institutions in the form of the DPR or DPRD, the Ministry of Home Affairs, the relevant local governments.

f. The team will compile a research report to serve as a recommendation for problem solving. In practice, the resolution of land disputes is not only carried out by the National Land Agency but can also be resolved by the General Courts and State Administrative Courts. If the general court focuses more on civil and criminal matters in land disputes, it is different with the state administrative court which resolves land disputes in relation to decrees issued by the National Land Agency or other regional officials relating to land.

At present, most land disputes in this case double certificates are resolved in 3 (three) ways, namely: 
a. The direct settlement by the parties by deliberation on the basis of deliberation for consensus is implied in the Pancasila as the basis of Indonesian social life and in the 1945 Constitution. Deliberations are held outside the court with or without a mediator. Mediators are usually from influential parties such as the Village Head, traditional leaders and of course the National Land Agency. In resolving land disputes through deliberation, one condition is that the dispute is not in the form of a determination of ownership of land which can give rights or diminish a person's rights to the disputed land, and among the disputing parties have strong objections and still adhere to local customary law.

b. Through arbitration and alternative dispute resolution Arbitration is the settlement of cases by one or more arbitrators (judges) who are appointed based on the agreement/agreement of the parties and it is agreed that the decisions taken are binding and final.

c. Dispute resolution through the judiciary

In accordance with the regulations in force in Indonesia, in general, land dispute resolution related to ownership disputes is submitted to the general court, against disputes over the decisions of the National Land Agency through the State Administrative Court and disputes regarding donated land submitted to the Religious Court. Based on the explanation of the specifications of the dispute resolution institutions, both litigation and non-litigation institutions, it is clear that all these methods cannot completely resolve land dispute problems in a short time, instead they tend to drag on. In fact, the mediation process carried out by the National Land Agency is unable to resolve existing land disputes, which is why it is very difficult for BPN to realize all of its vision, mission and strategic programs.

"The role of the State Administrative Court (PTUN), is only limited to examining the issuance of a Certificate of Property Rights, it does not see who owns it and that is the authority of the general court in this case civil. The relationship between the State Administrative Court (PTUN) and interested parties, namely the State Administrative Court (PTUN) is an institution that functions as a supervisor that carries out juridical supervision in the sense of supervision through legal processes, so if it is said that it is related to those who have an interest in The Ministry of Agrarian Affairs and Spatial Planning (ATR)/National Land Agency (BPN) later if there is a new dispute to the State Administrative Court (PTUN)."

The certificate cancellation procedure includes:

There are 2 ways of canceling a certificate cancellation of a decision, namely: 


\section{a. Through the courts;}

b. The official himself retracted. Regarding the court process, after the court incrach or has permanent legal force, BPN issues a revocation letter. If it is not done, it means that it is still registered, so it must be canceled and then removed so that it is removed.

The authority of the State Administrative Court, namely where the State Administrative Court is one of the executors of judicial power for the people who seek justice for State Administrative disputes who have the duty and authority to examine, decide, and resolve State Administrative disputes. In the event that a State Administration Agency or Official is authorized by or based on statutory regulations to resolve administratively a certain State Administration dispute, it is canceled or invalid, with or without the available claims for compensation and/or administration. The new court has the authority to examine, decide, and resolve State Administrative disputes.

\subsection{Constraints in resolving cases of double certified land rights}

In general, the causes of double certificate cases include:

a. Constraints from the community or land owners themselves who do not pay attention to the land they own and are not properly utilized so that it can be taken over by other people who claim ownership of the land because they feel that the land is empty land that has no owner even though the land already has a certificate previously published. Not only because the land is not paid attention and is used properly by the owner of the land but also sometimes cases of double certificate can occur because the community itself or the land owner does not know the location of the land they own based on the basis of the rights they hold usually occurs in cases of land given or inheritance from the parents of the land owner. Because they want to register a Hak Milik certificate and want the land certificate to be issued, and because the land owner does not know the location of the land, the land owner only estimates the location of the land based on the available details, then the location is measured which is considered part of the land as the location of the land owner but it turns out to have owned the land certificate. And the factors causing the double certificate case are caused by the community itself or the land owner, namely the bad faith of the community or the land owner itself, for example, a land owner who already has a certificate mortgage his land certificate at the Bank and sells the details to someone else;

b. Constraints from the village or sub-district government, that the occurrence of double certificate cases can be caused by technical factors in the sense of the mapping system because there is still a lack of village government that has maps or map facilities and because the land mapping facility was new in 1997 then what happened when the land was measured should be mapping This was done first and 
then the land certificate was issued, but because the final condition that was issued was the land certificate first, then the mapping was carried out. Should a certificate of a plot of land not be issued if mapping or map facilities are not available;

c. The causative factor for the subsequent double certificate case was the problem of land data documentation in the Village government, to make a land certificate must first apply for a cover letter from the village office, but what happened in one land that previously had a certificate was later claimed by another person and asked a sporadic cover letter is made from the village, because of the change in the Village Head, the new Village Head who does not know that the land already has a certificate will issue a certificate sporadically based on the community's request to issue the land certificate. Indeed, in relation to the management of a certificate, there must be an introduction from the sub-district with the signature of the head of the village and the head of the RT/RW. However, because there was a change in Village Head and who did not communicate with the previous Village Head or the head of the RT/RW so at the time of signing the file, it was easy to make a sporadic certificate without knowing that the land already had a land certificate or not. Not to mention the cases of land where the parcel number and final number are not registered in the Village book but the land has been controlled by the party concerned because it is supposed to issue a sporadic certificate, first checking the parcel number in Book $\mathrm{F}$ of the Village, but not yet all urban villages that have Book $F$ as proof of parcel number or as a reference and filter tools before the issuance of a sporadic certificate by the Village.

d. The right to build and the right to cultivate a land certificate that is supposed to issue a land certificate at the Ministry of Agrarian Affairs and Spatial Planning (ATR)/National Land Agency (BPN) must first look at the land master book as a reference for whether or not a land certificate has been issued. For example, a request for the issuance of a replacement certificate due to loss is not accompanied by a statement under oath by the right holder or the person who has lost it. The application for the issuance of a replacement certificate due to loss is not accompanied by a Statement of No Physical Change in the Field/Dispute. For example, a request for the issuance of a replacement certificate due to loss is not accompanied by a statement under oath by the right holder or the person who has lost it. The application for the issuance of a replacement certificate due to loss is not accompanied by a Statement of No Physical Change in the Field/Dispute. For example, a request for the issuance of a replacement certificate due to loss is not accompanied by a statement under oath by the right holder or the person who has lost it. The application for the issuance of a replacement certificate due to loss is not accompanied by a Statement of No Physical Change in the Field/Dispute.

\subsection{Solution to settlement of double certified land rights cases}

In today's era of globalization and economic liberalization, the role of land for various purposes will increase, both as a place to live and for business activities. In this regard, 
there will also be an increase in the need for support in the form of legal certainty in the land sector. The provision of legal certainty in the land sector requires the availability of a written, complete and clear legal instrument which is implemented consistently in accordance with the spirit and content of the provisions. In addition, in order to deal with various real cases, it is also necessary to carry out land registration activities that allow land rights holders to easily prove their rights to the land they control, and for interested parties, such as prospective buyers and potential creditors.

In this regard, Act No. 5 of 1960 concerning Basic Agrarian Principles, in Article 19 orders the holding of land registration in order to guarantee legal certainty in question. The implementation of land registration is then regulated in Government Regulation Number 10 of 1961 concerning Land Registration.

Meanwhile, the legal provisions contained in Government Regulation Number 10 of 1961 for the basis of its implementation are deemed not sufficient to provide the possibility for land registration to be carried out in an immediate time with more satisfactory results, so Government Regulation Number 10 of 1961 has been revised to become Government Regulation Number 24 of the of 1997 on Land Registration.

In Government Regulation No. 24 of 1997, the objectives and systems used are maintained, which in essence have been stipulated in the Basic Agrarian Law, namely that land registration is carried out in order to guarantee legal certainty in the land sector and that the publication system is a negative system, but contains a positive element, because it will produce letters of proof of rights which are valid as a strong means of proof, as stated in Article 19 paragraph (2) letter c, Article 23 paragraph (2), Article 32 paragraph (2) and Article 38 paragraph (2) UUPA. The sound of each article of the UUPA can be described as follows:

a. Article 19 paragraph (2) letter c, the registration referred to in paragraph (1) of this article includes the provision of certificates of proof of rights which are valid as a strong means of proof.

b. Article 23 paragraph (2), the registration referred to in paragraph (1) is a strong means of evidence regarding the abolition of property rights and the validity of the transfer and exemption of said rights.

c. Article 32 paragraph (2), the registration referred to in paragraph (1) is a strong means of evidence regarding the transfer and abolition of the right to cultivate, except in the case that the right is abolished due to the expiration of the period.

d. Article 38 paragraph (2) of the UUPA. The registration referred to in paragraph (1) is a strong means of evidence regarding the abolition of the right to build and the 
validity of the transfer of rights, except in cases where the rights are abolished due to the expiration of the period.

In addition, Article 32 paragraph (1) Government Regulation Number 24 of 1997 states that:

"A certificate is a proof of right which is valid as a strong means of proof regarding the physical data and juridical data contained therein, as long as the physical data and juridical data are in accordance with those in the measuring letter and the land book concerned".

This provision implies that as long as it has not been proven to the contrary, the physical data and juridical data included in the certificate must be accepted as true data, both in daily legal actions and in disputes in court, as long as the data is in accordance with what is stated in the letter. Measure and book the land ${ }^{7}$ concerned. In connection with the civil court cases that were examined and tried at the Purwokerto District Court regarding land disputes arising from double certificates, the question was raised, namely the extent to which legal protection can be provided by the State to holders of land rights. As it is understood that the right to legal protection is related to how the duties, roles and responsibilities should be carried out by a power with a state identity. As citizens who are united in a State identity, they certainly have rights that are human in nature, namely the right to safety, security and legal protection. As a consequence of the recognition of these rights, it is not permissible for any member of society as a citizen to receive unfair services from the power of the State.

\section{Closing}

In terms of resolving double certificate cases, there are two ways of resolving, namely through the mediation process at the Office of the Ministry of Agrarian Affairs and Spatial Planning (ATR)/National Land Agency (BPN) where summoned the two parties. parties to resolve the case and find a solution or win-win solution, but if there is no way out through the mediation process, the settlement is carried out through the litigation process or the settlement of the case in court,where in this case the involvement of the Ministry of Agrarian Affairs and Spatial Planning (ATR)/National Land Agency (BPN) is the defendant because it has issued a State Administrative Decree (KTUN) and if there has been a decision from the State Administrative Court (PTUN) in canceling one the certificate is invalid, so the State Administrative Court

\footnotetext{
${ }^{7}$ Alam, Bahrul., \& Khisni, Akhmad. (2020). Legal Protection of Holders of Land Loss Data In The City Land Office of Kendari. JURNAL AKTA: Vol.7, No. 2, 159-164. Retrieved from http://jurnal.unissula.ac.id/index.php/akta/article/view/7963
} 
obliges the Ministry of Agrarian Affairs and Spatial Planning (ATR)/National Land Agency (BPN) to revoke the certificate which has been declared canceled.

\section{References}

Journal:

Alam, Bahrul., \& Khisni, Akhmad. (2020). Legal Protection of Holders of Land Loss Data In The City Land Office of Kendari. JURNAL AKTA: Vol.7, No. 2, 159-164. Retrieved from http://jurnal.unissula.ac.id/index.php/akta/article/view/7963

Books:

[1] Harsono, Boedi. Hukum Agraria Indonesia, Sejarah Pembentukan Undang-Undang Pokok Agraria Isi dan Pelaksanaannya, Hukum Tanah Nasional Ed. 1. Jakarta: Djembatan

[2] Perangin, Effendi. (1994). Hukum Agraria di Indonesia, Suatu Telaah dari Sudut Pandang Praktisi Hukum. Jakarta: PT. Raja Grafindo Persada

[3] Saleh, K. Watjik. (1977). Hak Anda Atas Tanah. Jakarta: Ghalia Indonesia

[4] Salindeho, John. Masalah Tanah Dalam Pembangunan. Jakarta: Sinar Grafika

[5] Soekanto, Soerjono. (1982). Kesadaran Hukum dan Kepatuhan Hukum. Jakarta: CV. Rajawali

Seminar:

Harsono, Soni. Kegunaan Sertifikat dan Permasalahannya. Yogyakarta: National Seminar on 9 July 1992 